Studia Ceranea 1, 2011, p. 87-100

Sławomir Bralewski (Łódź)

\title{
The Porphyry Column in Constantinople and The Relics of The True Cross
}

The Porphyry Column standing in Constantinople has been given many names over the past centuries. It was called the Great Column, the Column of Constantine, at the end of the Byzantine Empire - The Column of the Cross. In today's Turkey, however, it is called the Burnt Column ${ }^{1}$ or the Hooped Column. The multiplicity of the names itself indicates its long history. Erected during the reign of Constantine the Great in $324-330^{2}$, it occupied a unique place in the history of Constantinople. It became a symbol of the city, featured in many legends. When the Tabula Peutingeriana was made, the original of which dates at the turn of the fourth and fifth century ${ }^{3}$, it showed the personification of Constantinople ${ }^{4}$ seated on a throne with an outline of a column on the right side, identified with the porphyry column of Constantine the Great ${ }^{5}$. The monument was an important landmark where imperial victories were celebrated. Triumphal procession would arrive at the Forum of Constantine to march around the Column chanting the canticle of Moses ${ }^{6}$. It was at the foot of the Column citizens would find salvation when their world, destroyed by enemies pillaging the city after breaking the defensive lines, would be turned into ruin. Later, it was believed that when the Turks would be storming the city, an angel with a sword will descend from the top of the Column and hand it to an unknown passer-by at the foot of the column, who will then lead the citizens of Constantinople and defeat the enemies ${ }^{7}$. This raises the question of the origins

1 It was destroyed by fire on several occasions; the greatest one took place in 1779.

2 Chronicon Paschale (ed. L. Dindorf, Bonnae 1832 [cetera: Chronicon Paschale], p. 528 [= CSHB]) and Theophanes (Chronographia, AM 5821, rec. C. DE Boor, Lipsiae 1883, p. 28 [cetera: Theophanes]) date the erection of the statue on the Column in 328. This date is uncertain, however, see C. MANGo, Le développement urbain de Constantinople (IVe-VII siècles), Paris 1985, p. 25, an. 14; S. BAssett, The Urban Image of Late Antique Constantinople, Cambridge 2004, p. 68.

3 G. Dagron, Naissance d'une capitale. Constantinople et ses institutions de 330 à 451, Paris 1974, p. 57.

4 K. Miller, Itineraria Romana, römische Reisewege an der Hand der Tabula Peutingeriana, Stuttgart 1916, passim; J.M.C. ToYnbeE, Roma and Constantinopolis in late-antique art from 312 to 365, JRS 37, 1947, p. 143-144, pl. IX, 1-2; E. Weber, Tabula Peutingeriana, Poznań 1998, p. 14, $20-21$.

5 G. DAGRON, op. cit., p. 58.

6 R. Janin, Constantinople byzantine. Développement urbain et répertoire topographique, Paris 1950, p. 82.

7 S. Andreae Sali vita auctore Nicephoro, sancti directore et confessario, 224, [in:] PG, vol. CXI, col. 868; Doukas, Historia Byzantina, ed. I. BeKker, Bonnae 1834, p. 289-290 [= CSHB]. 
of legends associated with the Porphyry Column. It seems that its foundations were laid as early as in the Early Byzantine period. In this article, I am attempting to explain what that tradition entailed and how the awareness of the Column's special significance for Constantinople and its citizens was established in the Early Byzantium.

It should be emphasized that the Porphyry Column was inextricably linked with Constantinople, the city founded by emperor Constantine the Great on the foundations of the existing Byzantium upon the Bosphorus River. Sources indicate that the ruler had originally intended to establish his seat elsewhere. The list of probable locations includes Troy, Chalcedon, Sardica and Thessalonica ${ }^{8}$. Choosing Troy would mean a symbolic return to the roots, since the ancestors of Rome were believed to have originated from there. Constantinople, according to Sozomenus ${ }^{9}$ and Philostorgius ${ }^{10}$, was founded with divine inspiration, as the law contained in the Code of Theodosius ${ }^{11}$ confirmed. According to the tradition associated with Eusebius of Caesarea, and thus dating back to the fourth century, the city of Constantine was dedicated to the God of martyrs ${ }^{12}$, in the opinion of Sozomenus, who was writing about a hundred years later, to Christ himself ${ }^{13}$. In later tradition, on the other hand, it was associated with the Mother of God ( $\Theta \varepsilon \circ \tau$ ókos) who was believed to have the city under her protection - the notion which was universally expressed in the eleventh century ${ }^{14}$.

By making Byzantium his seat and by naming it after himself, Constantine greatly expanded the urban area and conducted a series of construction works. He built city walls, the imperial loge at the hippodrome, the imperial palace and great alleys surrounded by porticos ${ }^{15}$. The urban plans completed at that time and quoted in sources included also

8 G. DAGRon, op. cit., p. 29.

9 Sozomène, Histoire ecclésiastique, II, 3, 3-4, ed. J. Bidez, Paris 1983 (cetera: Sozomenus),

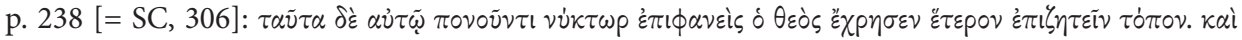

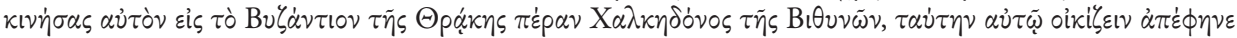

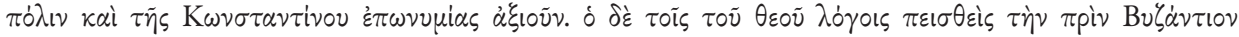

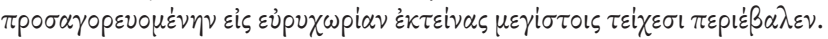

${ }_{10}$ Philostorgius, Kirchengeschichte. Mit dem Leben des Lucian on Antiochien und den Fragmenten eines arianischen Historiographen, II, 9, ed. J. Bidez, F. Winkelmann, Berlin 1981 (cetera: PhI-

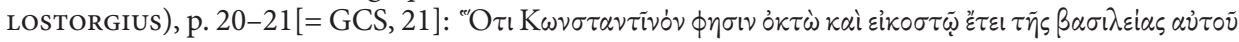

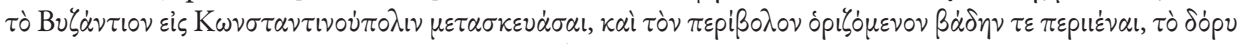

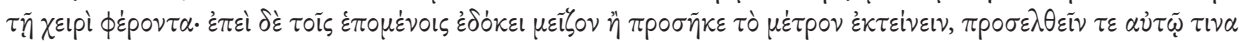

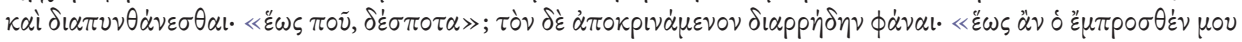

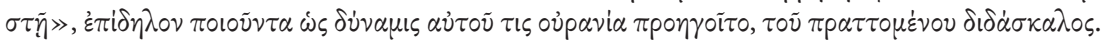

${ }^{11}$ Codex Theodosianus, XII, 5, 7, ed. P. KrUEger, Berolini 1923: urbis quam aeterno nomine Deo iubente donavimus.

${ }_{12}$ Eusebius, Vita Constantini, III, 48, ed. F. Winkelmann, Berlin 1992 (cetera: Eusebius), p. 98

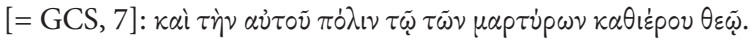

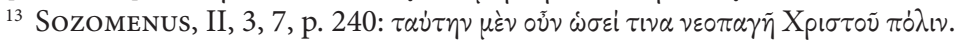

${ }^{14}$ G. DAgron, op. cit., p. 42. According to this author Constantinople was dedicated to Constantine himself. Cf. M. Hurbanič, História a mýtus. Avarský útok na Konštantinopol roku 626 v legendach, Prešov 2010, p. 19-21 [= Byzantinoslovaca/monografiae, 2].

${ }^{15}$ Chronicon Paschale, p. 527-529. 
the Forum of Constantine with the Porphyry Column. According to the account of Anna Comnena ( $\dagger 1153)$, it was clearly visible from all sides ${ }^{16}$. Raymond Janin thought that it was 50 meters high above the ground, and the core of the Column originally consisted of 9 cylindrical porphyry block joined together by a hoop imitating a laurel crown, which was meant to hide the actual joining point. According to Cyril Mango, on the other hand, the Column in the past was of a similar height as it is today, namely 37 meters. Today, it is a little lower, only 34.80 meters due to the difference in the levels of the ancient forum and the today's street ${ }^{17}$. He is also convinced that Raymond Janin was also mistaken as to the number of cylindrical blocks because he believes that there were seven at most - six visible today, and one walled up by the Turks, attempting to reinforce the construction of the Column after the fire which took place in $1779^{18}$.

According to the testimony of Anna Comnena, the Column was surmounted with a bronze statue facing the east ${ }^{19}$. Historiographers from earlier centuries, such as Philostorgius - the author of Church History from fifth century ${ }^{20}$, Hesychius Illustrious ${ }^{21}$ - a historian and a biographer from the mid-sixth century, John Malalas - a chronicler from the same century ${ }^{22}$, or the author of the Chronicon Paschale from the mid-seventh century $^{23}$ - they all associate the depiction with emperor Constantine. Later sources identify the aforementioned statue as Apollo ${ }^{24}$. It seems that it could be perceived differently; some people probably saw it as the emperor, others - as the god ${ }^{25}$. Philostorgius indicated that „enemy of God accuses the Christians of worshiping with sacrifices the image of Constantine set up upon the porphyry column, of paying homage to it with lamp-lighting and incense or praying to it as to a god, and of offering it supplica-

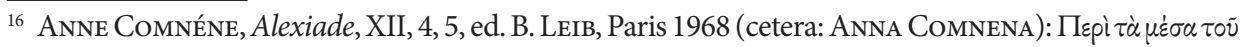

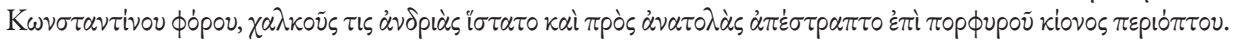
${ }^{17}$ C. Mango, Constantinopolitana, JDAI 80, 1965, p. 312-313.

${ }^{18}$ Ibidem, p. 310-312; IDEM, Constantine's Porphyry Column and the Chapel of St. Constantine, [in:] IDEM, Studies on Constantinople, Aldershot 1993, art. IV, p. 104; Raymond JANIN (op. cit., p. 84) dated the aforementioned works to 1701.

${ }^{19}$ Anna Comnena, XII, 4, 5.

20 Philostorgius, HE, II, 9a; II, 17, app. 7, 7a.

21 Hesychius Illustrius, Patria Constantinopoleos, 41, [in:] Scriptores originum Constantino-

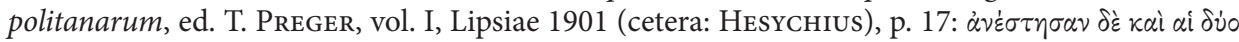

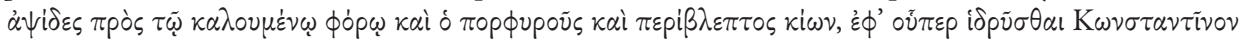

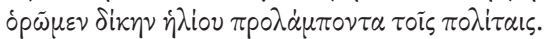

22 Ioannis Malalae Chronographia, XIII, 7, rec. I. ThuRn, Berolini-Novi Eboraci 2000 (cetera:

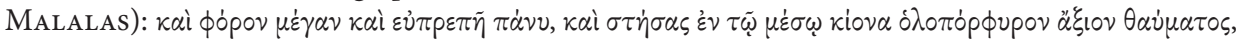

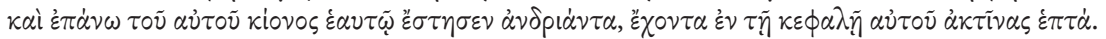

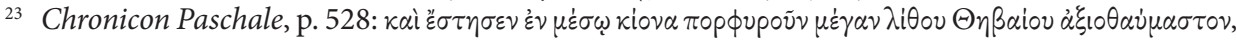

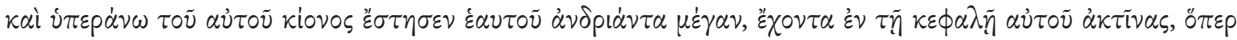

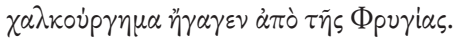

24 Since Pseudo-Codinus (Patria Constantinopoleos, 45, [in:] Scriptores originum..., vol. II, Lipsiae 1907 [cetera: Pseudo-Codinus], p. 174, 8).

25 G. Fowden, Constantine's Porphyry Column: the earliest literary allusion, JRS 81, 1991, p. 130; C. MANGo, Constantine's Column, [in:] IDEM, Studies on Constantinople..., art. III, p. 6.
} 
tions to avert calamities"26. Similar differences of opinion can be seen among scholars. According to Gilbert Dagron, it was the representation of Apollo that was placed on the Column ${ }^{27}$. Raymond Janin argued that it was a statue of Constantine Helios bearing the features of Apollo ${ }^{28}$. Adam Ziółkowski saw it as a statue of Christ, and Cyril Mango - a statue of Constantine, which the ruler commissioned for his Forum in Constantinople or for some other place outside the capital, where it was ultimately brought ${ }^{29}$.

Sources are also not consistent as to the origin of the statue $e^{30}$. John Malalas derived it from Troy ${ }^{31}$ but he mistakenly placed the latter in Phrygia because he was convinced that the city was founded by Tros, the king of Phrygia ${ }^{32}$. Troy was quoted as the place of the statue's origin by (after John Malalas) George the Monk ${ }^{33}$ and John Zonaras ${ }^{34}$, and Phrygia itself was quoted by the author of Chronicon Paschale ${ }^{35}$; Michael Glykas maintained the same, indicating moreover a specific place in Phrygia - Heliopolis ${ }^{36}$. Cedrenus, on the other hand, presented an original idea, arguing that a statue came from Athens and was made by Phidias ${ }^{37}$. As can be expected, associating this particular statue with Troy, the statue which - along with the column on which it was placed - became a symbol of Constantinople, was not accidental. Thus, a reference was made to the tradition linking the protoplasts of Rome with Troy. It is possible that the statue was actually made there. It seems very likely, considering the account by Sozomenus on Constantine's original choice of Troy as the capital. Sozomenus even mentioned the commencement of construction work there. The statue could be made at that very time and, after the decision as to the location of the seat of the ruler changed, it was moved to a new place in Constantinople ${ }^{38}$.

26 Philostorgius, HE, II, 17 (trans. Ph.R. Amidon, ed. 2007, p. 35).

27 G. Dagron, op. cit., p. 38.

28 R. JANIN, op. cit., p. 82.

29 According to Adam ZióŁkowski (Sokrates Scholastyk, Historia Kościoła, I, 17, trans. S. KAZIKowski, intr. E. WiPszYcKA, comm. A. Zıó£Kowski, Warszawa 1986, p. 111, an. 97) This giant statue was in fact a statue of Christ as the Sun of the Faith, which explains why the relics were placed in it. Cf. C. Mango, Constantine's Column..., p. 3-4.

${ }^{30}$ G. Dagron, op. cit., p. 38.

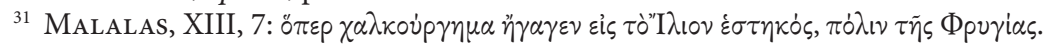

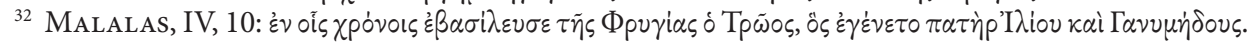
O

${ }^{33}$ Georgius Monachus, Chronicon, ed. C. DE Boor, Lipsiae 1904 (cetera: Georgius MonachUs), p. 500 [= BSGR].

${ }^{34}$ Ioannis Zonarae Epitome historiarum libri XIII-XVIII, XIII, 3, 25-26, vol. III, ed. TH. BÜtTnERWoBst, Bonnae 1897 (cetera: ZonARAs), p. 180.

${ }^{35}$ Chronicon Paschale, p. 528; cf. above an. 22.

${ }^{36}$ Michael Glykas, Annales, ed. I. Bekker, Bonnae 1836 (cetera: Glykas), p. 464 [= CSHB].

${ }^{37}$ Georgius Cedrenus, Historiarum compendium, ed. I. Bekker, Bonnae 1838, vol. I (cetera: Cedrenus), p. 518 [= CSHB].

${ }^{38}$ C. Mango, Constantine's Column..., p. 4. Gilbert Dagron believes (op. cit., p. 38) the origins of the statue to be an issue of significance. The combination of the dynasty's Apollonistic tradition with Troy as the original place of worship of the statue could indicate to Constantine's willingness of the unification of the Hellenistic with the Roman. 
The statue probably resembled the image of Sol Invictus which appears on coins. If it was indeed a depiction of the emperor Constantine, he was probably portrayed in military attire ${ }^{39}$. The figure on top of the Column had a crown on its head adorned with seven sun rays, which were later interpreted as the nails of Christ's Passion ${ }^{40}$. In addition, in its left hand, it held a bronze globe ${ }^{41}$, surmounted by a winged Victoria, and, according to Nicephorus Callistus - with a cross, which apparently contained a relic of the Holy Cross ${ }^{42}$. As it seems, however, Callistus could be describing one of the subsequent globes. As a result of earthquakes, the first two came apart in the years $477^{43}$ and $869^{44}$. In the right hand, the figure was holding a spear $\left(\lambda \circ \gamma^{\prime} \chi \eta\right)$, as attested by John Malalas $^{45}$, Theophanes ${ }^{46}$ and Cedrenus ${ }^{47}$ or a scepter $(\sigma \kappa \tilde{\eta} \pi \tau p o v)$, as Anna Comnena ${ }^{48}$ maintained. In the iconography, the statue crowning the Column usually is holding a spear. This is consistent with the account given by Philostorgius, according to whom

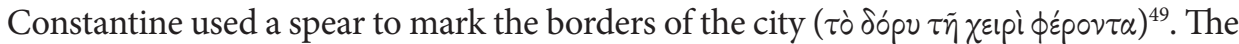
attribute in question was to fall off from the statue during the earthquake of 541, as Theophanes argues ${ }^{50}$, or 554, according to the accounts by Cedrenus and Malalas ${ }^{51}$.

In the account by Anna Comnena, the citizens of Constantinople called the statue Anthelios or Anelios and all efforts to replace this name with the name of the emperor Constantine failed ${ }^{52}$. Michael Glykas informs of the destruction brought by a lightning which struck in 1079 , when three iron hoops were $\operatorname{torn}^{53}$, probably

\footnotetext{
${ }^{39}$ According to Sarah BassetT (op. cit., p. 68), Constantine depicted on the statue was nude.

${ }^{40}$ John Malalas (XIII, 7) was the one to write of the seven rays, and after him - George the Monk (Georgius Monachus, p. 500), while the rays as the nails used at the crucifixion of Christ are mentioned by Pseudo-Codinus (45, p. 174) and Zonaras (XIII, 3); cf. C. Mango, Constantine's Column..., p. 3; IDEM, Constantine's Porphyry Column..., p. 109.

${ }^{41}$ Anna Comnena, XII, 4, 5.

${ }^{42}$ Nicephorus Callistus Xanthopoulos, Historia ecclesiastica, VII, 49 (cetera: Nicephorus Callistus), [in:] PG, vol. CXLV, col. 1325 CD.

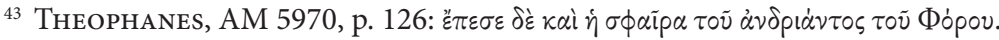

${ }^{44}$ Leo Grammaticus, Chronographia, ed. I. BekKer, Bonnae 1842 (cetera: Leo Grammaticus), p. 254.

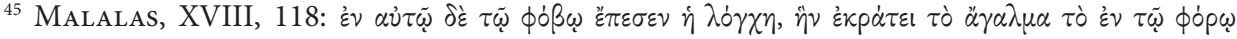

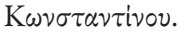

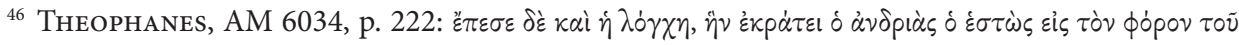

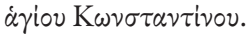

${ }^{47}$ Cedrenus, p. 656.

${ }^{48}$ AnNa Comnena, XII, 4, 5: $\sigma \kappa \tilde{\eta} \pi \tau$. $\kappa \alpha \tau \alpha \sigma \kappa \varepsilon \nu \alpha \sigma \theta \varepsilon \bar{\sigma} \sigma \alpha \nu$. However, when Anna Comnena was writing her work, the statue had been absent from the Column for over forty years.

${ }^{49}$ Philostorgius, II, 9, p. 21; cf. G. Dagron, op. cit., p. 38, an. 6.

50 Theophanes, AM 6034, p. 222.

${ }^{51}$ Malalas, XVIII, 118; Cedrenus, p. 656.

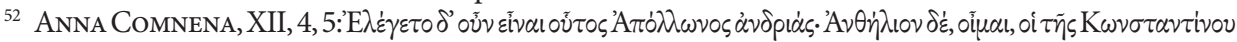

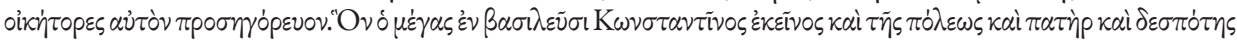

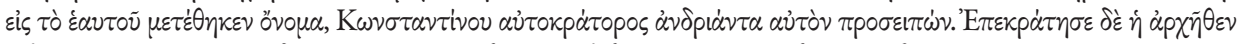

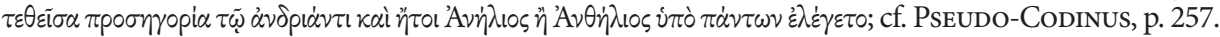

${ }^{53}$ GlyKas, p. 617.
} 
those which were mounted in order to reinforce the Column during the reign of Theodosius II in $416^{54}$. On April $5^{\text {th }}, 1106$, a violent southern wind knocked the statue to the ground ${ }^{55}$, causing casualties ${ }^{56}$, which was treated as a bad sign by opponents of the ruling emperor, Alexius I Comnenus, an ill omen of the imminent death of the ruler. Emperor Manuel I Comnenus (1143-1180) had the monument repaired. On top of it ten rows of stones were laid, fused with concrete, and a marble block was placed there, probably giving it the shape of the Corinthian capitol. However, from that moment, the Column was topped with a cross instead of the statue ${ }^{57}$. The emperor also had a commemorative inscription placed under the column, reading: Manuel, the pious ruler, restored this God's work destroyed by time ${ }^{58}$. The column was bound with metal hoops, in the eighteenth century due to the threat of earthquakes.

The Column was placed on a high pedestal, which was in turn embedded on a broad a square platform with each side 8.35 meter wide ${ }^{59}$. A drawing by Melchior Lorck, dating to 1561, suggests that the Column base was decorated with bas-relief known as aurum coronarium. However, no other source has been found to confirm it ${ }^{60}$. According to Nicephorus Callistus, there were arches adjacent to the plinth of the Column on each side, which opened to the Forum of Constantine ${ }^{61}$. Raymond Janin was convinced that under one of these arches a small oratory was located - the Chapel of St. Constantine ${ }^{62}$, where each year official processions came ${ }^{63}$. Earlier, it was believed that this oratorio was located at the base of the Column; however, research has shown that it was a solid structure ${ }^{64}$. According to Cyril Mango, the chapel, probably built in the period of iconoclasm, was adjacent to the Column plinth on the north side. The aforementioned arches were added only during the renovation of the Column after the crash in 1106, when the wind from the south knocked the statue, causing much destruction and probably also damaging the chapel, which was never rebuilt. After the tenth century, the Chapel of Constantine is no longer mentioned in the sources. This is probably because at that time the emperor Constantine ceased to be regarded as the patron of the city and the empire, as that role

${ }^{54}$ Chronicon Paschale, p. 573.

${ }^{55}$ Anna Comnena, XII, 4, 5. In the opinion of Raymond Janin (op. cit., p. 83) three cylinders were knocked off along with the statue, the notion, however, is rejected by Cyril MANGo (Constantinopolitana..., p. 310), arguing that there is no source information to confirm it.

${ }^{56} 10$ people are said to have died on that occasion, cf. C. Mango, Constantine's Porphyry Column..., p. 108.

${ }^{57}$ C. MAngo, Constantinopolitana..., p. 312.

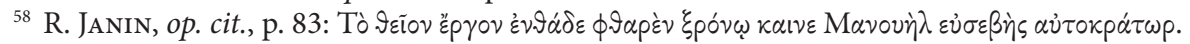

${ }^{59}$ C. Mango, Constantine's Porhyry Column..., p. 104.

${ }^{60}$ IDEM, Constantinopolitana..., p. 308-311.

${ }^{61}$ Nicephorus Callistus, VII, 49.

${ }^{62}$ Constantini Porphyrogeniti imperatoris De cerimoniis aulae Byzantinae, I, 1, 24, ed. J. ReIsKe, Bonnae 1829, vol. I (cetera: De cerimoniis), p. 29-30 [= CSHB].

${ }^{63}$ De cerimoniis, I, 10, 3.

${ }^{64}$ R. JANIN, op. cit., p. 81. 


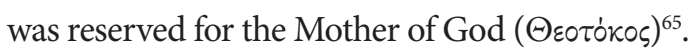

It is also thought that originally an altar was placed by the plinth of the Column situated in the ancient fashion over the Mundus (the image of the entrance to the underworld), where sacrifices were usually made to the underground gods. According to tradition, under the base of the column an archaic statue of Pallas was to be buried, called Palladium $^{66}$, secretly brought out of Rome by Constantine ${ }^{67}$. It probably originated from the belief that the ruler wished to ensure good fortune for Constantinople. Thus, both cities during their prosperity were to be under the care of the same goddess. Perhaps the collapse of the Old Rome, which occurred in the fifth century, inspired the contemporary thought of losing the favor of Pallas to Constantinople - the New Rome. It also emphasized the continuity of the existence of Rome in its new form, as the city of Constantine was considered, as well as referred to the choice of the location for the new capital, which initially was supposed to be Troy ${ }^{68}$.

It was said also that in the plinth, in the statue or atop of the Column various magic items and relics were concealed. John Diacrinomenus mentioned gold coins with the likeness of Constantine imprinted on them, which were a symbol of prosperity ${ }^{69}$. Later Christian tradition late added the information of holy relics: a portion of the True Cross (Vera Crux), baskets from the multiplication of bread, a vase of holy oil (the chrism), Noah's axe handle, the rock from which water sprang at the command of Moses, nails from the Passion of Christ, relics of saints, wood from the crosses of the two thieves and pots of perfume ${ }^{70}$. In this way, the Column became sacred in itself in the social consciousness.

Tradition has retained three dedications of late origin, which were to be placed

${ }^{65}$ C. Mango, Constantine's Porhyry Column..., p. 109-110.

${ }^{66}$ Procopius Caesariensis, De bello Gothico, I, 15, 14, [in:] Procopii Caesariensis opera om-

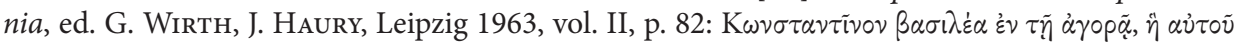

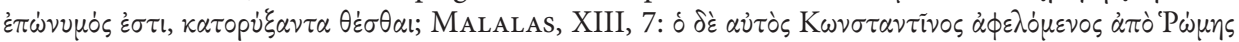

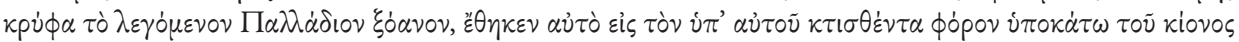

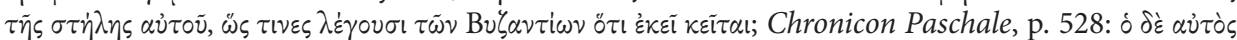

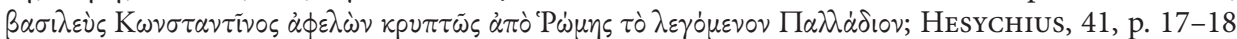
(addition from the eleventh century); Pseudo-Codinus, 45, p. 174; G. DAGron, op. cit., p. 30; C. DieHL, Dequelques croyances byzantines sur la fin de Constantinople, BZ30, 1929/1930, p. 192-196; A. Alföldi, On the foundation of Constantinople, a few notes, JRS 37, 1947, p. 11.

${ }^{67}$ G. Dagron, op. cit., p. 39; S. BAssett, op. cit., p. 69-70.

68 Sozomenus, II, 3.

69 Parastaseis syntomoi chronikai, 56 (cetera: Parastaseis), [in:] Scriptores originum..., vol. I, p. 56-

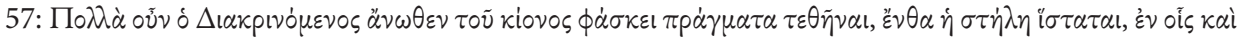

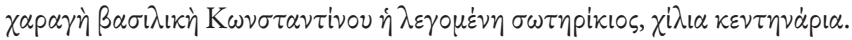

70 Socrates, Kirchengeschichte, I, 17, ed. G.C. Hansen, Berlin 1995 (cetera: Socrates) [= GCS, 1]; Georgius Monachus, p. 500; Andreae Sali vita, 224, [in:] PG, vol. CXI, col. 868; HesYchiUs, 41, p. 17; M. Guidi, Un Bios di Constantino, Rome 1908, p. 37, 15-22; A. Frolow, La dédicace de Constantinople dans la tradition byzantine, RHR 127, 1944, p. 77, an. 1-2; A. KAZHDAN, „Constantin imaginaire": Byzantine Legends of the ninth century about Constantine the Great, B 57, 1987, p. 233. 
at the base of the Column. The first one, pagan, To Constantine, who shines like the Sun (Helios) $^{71}$; the second, inspired by Vita Constantini by Eusebius ${ }^{72}$ and the text by Sozomenus ${ }^{73}$ : To you, Christ, God, I entrust the city $^{74}$; third one, the most literary: To thee, Christ, who art the creator and ruler of the world, to thee I entrust this city which is thine, like the scepter and the power of Rome. Save it and deliver it from all calamity. ${ }^{75}$ Thus, the statue was perceived by the authors of source texts both as a Christian and pagan monument. The representation of Christ as the god of sun and these dedications addressed to him became the basis for the suggestion that the Column was surmounted with a statue of Christ himself ${ }^{76}$. It is possible that Christians began to see the Column as a sacred monument because of a widespread belief that it housed sacred relics.

The Porphyry Column played an important role in the ceremony of the foundation of Constantinople, which was divided into two stages ${ }^{77}$. Celebrations began with an official procession, going from Philadelphion or Magnaura to the Forum of Constantine, to place the statue and holy relics on the Column ${ }^{78}$. The festive procession was composed of Christians, led by priests, chanting hymns and entrusting Constantinople to God's care with the words of a prayer: Keep it (the city) in prosperity until the end of time, our Lord, and reciting the Kyrie eleison ${ }^{79}$.

The second phase of the foundation ceremony, called pompa circensis, which took place on 11 May $330 \mathrm{AD}$, was, on the command of emperor Constantine himself, repeated annually on the day when the anniversary of the founding of the city was celebrated on the hippodrome ${ }^{80}$. A wooden statue covered with gold, probably

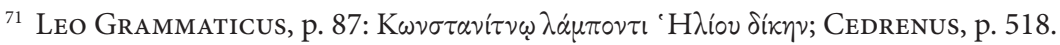

${ }^{72}$ Eusebius, III, 48, p. 98.

${ }^{73}$ Sozomenus, II, 3, 7, p. 240.

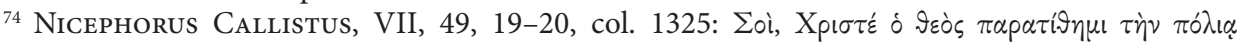
$\tau \alpha \dot{\tau} \tau \eta$.

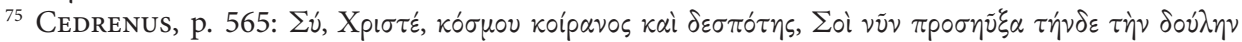

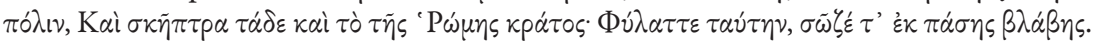

${ }^{76}$ More on the subject of the association of the worship of Christ with the solar cult, see H. CHADwICK, Kościót w epoce wczesnego chrześcijaństwa, trans. A. Wypustek, Warszawa 2004, p. 125-126. Suggestions associating the statue with Christ are rejected by Cyril MANGO (Constantine's Column..., p. 6).

77 Glykas, p. 617; Zonaras, XIII, 3, 26-27; G. Dagron, op. cit., p. 37; R. Janin, op. cit., p. 77-80.

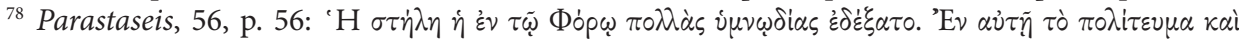

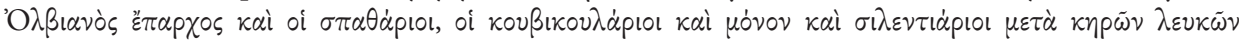

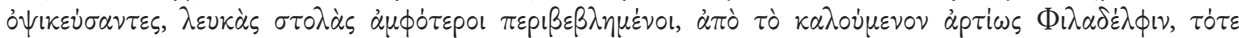

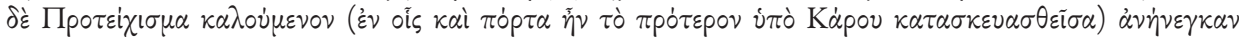

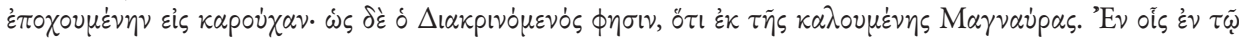

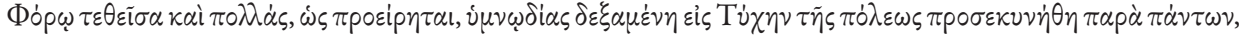

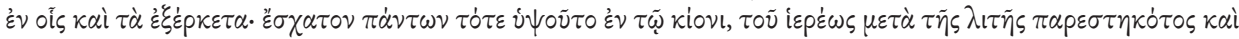

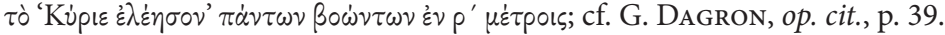

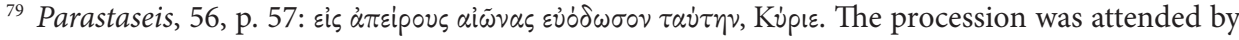
prefect Olbianus.

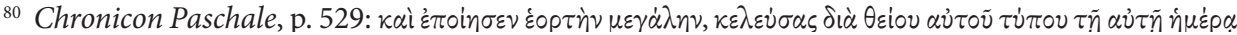


a replica of the statue on the Porphyry Column, was solemnly brought in a chariot into the hippodrome ${ }^{81}$. The depicted figure had a crown of rays and in its right hand was, also gilded, the Tyche of the city. Most likely, it was a globe surmounted by Victoria rather than a figural personification of Constantinople. The statue was accompanied by a squad of soldiers (dressed in chlamys and campagi boots), each of whom was holding in his hand a white candle. When the chariot on which the statue was placed circled the hippodrome, it stopped in front of the imperial box, and the currently reigning emperor rose and gave a deep bow before the statue and the representation of Tyche of the city. At the end of the ceremony, the people chanted hymns and worshiped at these depictions by adoration ${ }^{82}$. Thus, in the pompa circensis ceremony, the chariot carrying the statue had its triumphant run, setting off from carceres, circling the spina and coming to a stop in front of the imperial tribune.

The author of the Chronicon Paschale identified the chariot as ${ }^{\prime \prime} \chi \eta \mu \alpha^{83}$, and the Parastaseis syntomoi chronikai pointed to its solar character, calling it a $\dot{\eta} \lambda i_{0} v \ddot{p} \mu \alpha^{84}$. A similar term was used by Pseudo-Codinus ${ }^{85}$, in whose opinion the statue crowning the column at the Forum of Constantine depicted Apollo ${ }^{86}$. According to Gilbert Dagron, in the hippodrome, Constantine-Helios from the Porphyry Column became a coachman driving his solar $\operatorname{chariot}^{87}$.

This ceremony, according to some sources, was to continue until the reign of Julian (361-363), when the emperor was to recommend the gilded statue to be buried because of the cross adorning $\mathrm{it}^{88}$. Pseudo-Codinus, on the other hand, at one point associates the ceremony abolition with $\operatorname{Julian}^{89}$, and another time with Theodosius the Great ${ }^{90}$, while John Malalas ( $†$ 578) asserted that this ceremony took place even in his day ${ }^{91}$. It seems likely that the real reason for the abolition of the adoration ceremony could be that it was

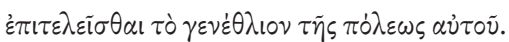

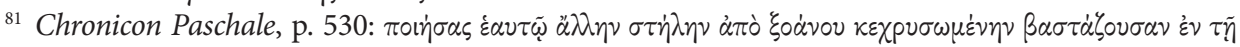

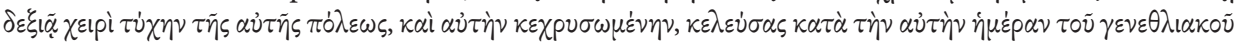

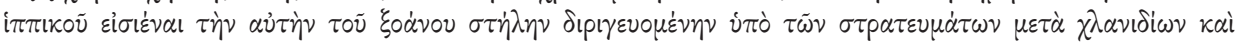

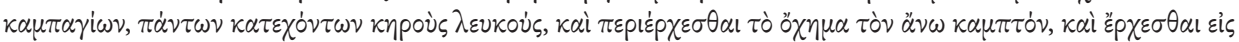

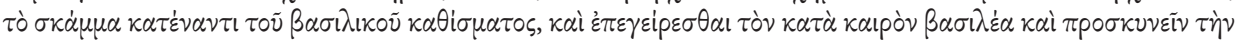

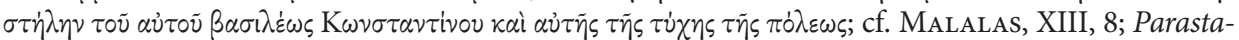
seis, 38, 56, p. 42, 56; Pseudo-Codinus, 42, 49, 87, p. 172-173, 177-178, 195-196.

82 Parastaseis, 56, p. 56-57; Pseudo-Codinus, 49, p. 177.

${ }^{83}$ Chronicon Paschale, p. 530.

${ }^{84}$ Parastaseis, 38, p. 42.

85 Pseudo-Codinus, 42, p. 172.

${ }^{86}$ Pseudo-Codinus, 45, p. 174.

${ }^{87}$ G. Dagron, op. cit., p. 307: Le Constantin-Helios de la colonne de porphyre devient à l'Hippodrome le conducteur du char du Soleil.

${ }^{88}$ Parastaseis, 38, p. 42.

89 Pseudo-Codinus, 42, p. 173.

90 Pseudo-Codinus, 87, p. 196.

${ }^{91}$ Malalas, XIII, 8. 
deemed too pagan ${ }^{92}$. Presumably, it survived only in the form of festivities and food distribution, which is confirmed to be happening as late as in the tenth century ${ }^{93}$.

Thus, the Porphyry Column with the statue, and since the reign of Manuel I Comnenus (1143-1180) - with the cross which replaced the latter, remained throughout the history of the Byzantine Empire a symbol of Constantinople and its foundation, as well as the divine protection over the city. In addition, in early Byzantium, it presumably united the ideas of paganism and Christianity, becoming sacred to pagans and Christians alike. It must seem extremely interesting, therefore, how it was presented by Constantinople church historians in the mid-fifth century - Socrates and his successor, Hermias Sozomenus.

Socrates in his Ecclesiastical History refers to the Porphyry Columns twice. The first time he describes the circumstances under which the relics of the Holy Cross were found by Helena, the mother of Constantine the Great ${ }^{94}$; the second time - when he presents the circumstances of the death of heresiarch Arius ${ }^{95}$. In the first case, he refers to the Column as the place where the relics of the Holy Cross Tree were deposited ${ }^{96}$. The emperor, having received them from his mother, convinced that the city where such holy items are kept would never perish, was to order them to be hidden in the Porphyry Column ${ }^{97}$. In the second case, according to the account by Socrates, Arius, having deceived the emperor Constantine as to his faith, boasting about his triumph, left the imperial palace following the route along which rulers usually celebrated their victories ${ }^{98}$. When he arrived at the

${ }_{92}$ G. Dagron, op. cit., p. 90.

${ }_{93}$ De ceremoniis, I, 70.

${ }^{94}$ Socrates, I, 17. The relics of the Holy Cross were found probably in the twenties of the fourth century, but the tradition of linking their discovery to Helena is a few decades older, see J.W. DRIJvers, Helena Augusta. The mother of Constantine the Great and the legend of her finding of the True Cross, Leiden-New York-København-Köln 1992, p. 89, 93 and also S. BorgeHAmmaR, How the Holy Cross was found. From the event to medieval legend, Stockholm 1991, p. 31-53; B. BAERT, A Heritage of Holy Wood. The Legend of the True Cross in Text and Image, Leiden 2004; H.A. KLEIN, Byzanz, der Westen und das 'wahre' Kreuz. Die Geschichte einer Reliquie und ihrer künstlerischen Fassung in Byzanz und im Abendland, Wiesbaden 2004. More on the subject of Eusebius' silence on the aforementioned relics, see J.W. Drijvers, op. cit., p. 83-89; H.A. Drake, Eusebius on the True Cross, JEH 36, 1985, p. 1-22; S. BorgehammaR, op. cit., p. 116-117.

${ }^{95}$ Socrates, I, 38.

${ }^{96}$ The relics of the Holy Cross were distributed to various places in the Imperium Romanum (Cf. J.W. Drijvers, op. cit., p. 89-92), according to Cyril of Jerusalem (Catechesis, X, 19, [in:] PG, vol. XXXIII, col. $685 \mathrm{~B})$, they were located all over the world.

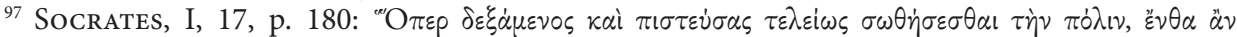

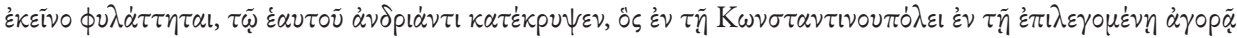

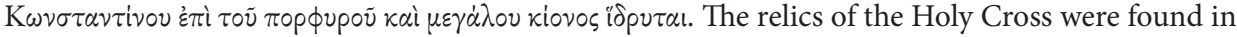
the twenties of the fourth century, and thus at the time when the Porphyry Column was erected. Placing these relics in there was therefore possible from a chronological point of view. However, apart from Socrates, only George the Monk mentions it (Georgius Monachus, p. 500).

${ }^{98}$ In the opposite direction, however, than the rulers did. 
Forum of Constantine, where the column of porphyry stands ${ }^{99}$, as Socrates points out, he came down with terrible stomach pains, which led to his death by his entrails falling out; Arius was to meet his end in the latrine at the back of the Forum.

The historian's account on the Column is, therefore, on the one hand, very laconic, on the other, very eloquent. Because of the relics of the Holy Cross, the Column became sacred, as the heresiarch learned himself. He deceived the ruler but was not able to deceive God and was exposed at the moment when in his pride he approached the sacred item which the Column had already become by then. Interestingly, in the work of Socrates, the monument appears only in stories of legendary character. Thus, Socrates referred to the legend already at that time associated with the sanctity of the Column. He must have been aware of this issue. Writing about the hidden relic in the Holy Cross, he added that he included that detail on the basis of a verbal account, and nearly all the citizens of Constantinople contend that it is consistent with the truth ${ }^{100}$. It is possible that the relics in question was attributed the same role as the pagan Tyche of the city played, since in the opinion of Constantine, according to Socrates, it was meant to ensure the continuance of Constantinople and it was to be so for the eternity. The City in which the said relic was kept was not to be destroyed. The Porphyry Column has the same significance in the eyes of pagans and Christians - for other reasons, however. In the opinion of the former, it was to be guaranteed by the Palladium and the representation of Tyche, crowning a sphere held by the statue, while the latter believed that it was ensured by the relics of the Holy Cross.

How was this legend addressed by Sozomenus, who, according to many researchers improved and reinterpreted the Ecclesiastical History by Socrates? ${ }^{101}$ In fact, Sozomenus did not mention the Porphyry Column at all, not even once. Neither did he refer to it when he informed of the discovery of the relic of the Holy Cross of Christ, ${ }^{102}$ nor when he

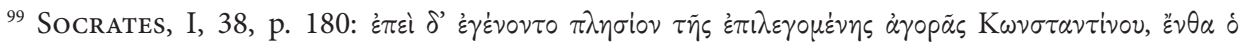

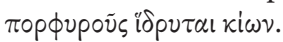

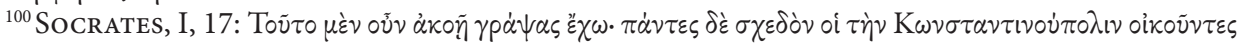

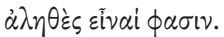

${ }^{101}$ It was pointed out on numerous occasions, see G.F. Chesnut, The first Christian Histories: Eusebius, Socrates, Sozomenus, Theodoret, and Evagrius, Paris 1977, p. 205; G. SABвAH, Introduction, [in:] Sozomenus, vol. II, p. 59 [= SC, 477]; F. Young, From Nicaea to Chalcedon, London 1983, p. 32; T.D. Barnes, Athanasius and Constantius, Cambridge 1993, p. 206; T. URBAINCZYK, Observations on the differences between the Church Histories of Socrates and Sozomenus, Hi 46, 1997, p. 355-356. P. JANISZEWSKI believes (Żywioly w stużbie propagandy, czyli po czyjej stronie stoi Bóg. Studium klęsk i rzadkich fenomenów przyrodniczych u historyków Kościoła w IV i V wieku, [in:] Chrześcijaństwo u schyłku starożytności, vol. III, ed. E. WipszYCKA, Kraków 2000, p. 153) that Sozomenus "wanted to create a work that would compete with Socrates and be closer to the canons of classic literature and the taste of the classically inclined intellectual circles of Constantinople". More on the subject of differences between the works by Socrates and Sozomenus cf. P. van Nuffelen, Un héritage de Paix et de Piété. Étude sur les histoires ecclésiastiques de Socrate et de Sozomène, Leuven-Paris-Dudley 2004, passim.

${ }^{102}$ Sozomenus, II, 1.
} 
wrote about the death of Arius ${ }^{103}$. In the first case, his account is consistent with the story by Socrates. The discovery of the tree of the Holy Cross was made possible through God's help, shortly after the Council of Nicaea, when the mother of the emperor, Helena, was staying in Jerusalem ${ }^{104}$. In a miraculous way, with the participation of Macarius, the bishop of Jerusalem, the Cross of Christ was distinguished from the crosses of the two thieves, thanks to the healing of a dying woman. Both of them, Socrates and Sozomenus, also stressed that a part of the relic is kept in Jerusalem in a silver box and Helena sent another part to Constantine, like the nails from the Passion of Christ. The two accounts are different in some of the details. In the account of Socrates, the mother of the emperor went to Jerusalem as a result of prophetic visions she received in her dreams, while in the text by Sozomenus she came there at the time when her son decided to erect a temple in Jerusalem near Golgotha, and the purpose of her pilgrimage was her religious passion - the desire to pray and explore holy places. Finding the tree of the Holy Cross was only her great desire. Thus, in the work of Socrates, Helena plays an active role in the search for relics, ordering the relevant work to be performed, while in Sozomenus' account she is only a witness of their discovery during the works undertaken at the command of the ruler. According to Socrates, the woman healed by touching the Cross was a resident of Constantinople, while in the opinion of Sozomenus she belonged to the elite of Jerusalem. Helena assisted at her healing, which Socrates does not mention explicitly. The issue of the healed women appears to be a seemingly minor detail. In Jerusalem, however, there were probably a number of seriously ill people. The fact that in the account by Socrates it is a woman that is healed - a resident of Constantinople, bears some significance. As can be expected, in this way Socrates wanted to express the belief in the importance of the relics of the Cross for the future of the capital, since the discovery of the true Cross of Christ saved the resident of the city. In addition, it also seems that her gender is not without importance either. Personifications of cities were in fact female. Perhaps, therefore, Socrates saw in that healed woman a symbol of the city itself? Sozomenus did not share the views of his predecessor on this issue. Most likely, it was his approach to the Porphyry Column that distinguished him from Socrates, because he also held the relics of the Cross in great esteem. The historians agree as to the actual nature of the facts they are quoting, they only differ as regards the details, including the most important ones concerning the role of the emperor's mother, and placing the relics in the Porphyry Column.

It is interesting that Sozomenus, like Socrates, felt it necessary to validate his account on the subject, quoting sources of the information provided. He indicated then that he acquired it from people who were knowledgeable, who told the story from generation

${ }^{103}$ Sozomenus, II, 30.

${ }^{104}$ To Sozomenus, it was more probable that God gave direct guidance on this issue, although the historian does not rule out that the relevant information was delivered by a Hebrew man. The legend of Inventio Crucis, whose origin dates back to 415-450 identified him as Judah-Cyriacus; see S. Borgehammar, op. cit., p. 146-161. 
to generation as well as from written accounts, which he had at his disposal. Significantly, too, that Socrates gave a similar confession about the origin of the facts which he was describing; he did that elsewhere, however, unlike Sozomenus, his successor. Socrates introduced the relevant passage immediately following the information about placing the relics of the Holy Cross in Porphyry Column while Sozomenus, ignoring or rejecting this fact, concluded the account on the finding of the Cross of Christ in this way, as though he wanted to use his words to counterbalance the testimony of Socrates and on the subject of the Column. Thus, it can be asserted that the omission of information about the deposit of relics in the Column of Constantine was not accidental.

As for the description of the death of Arius, also this time the two accounts are consistent in their nature. The heresiarch met his end in a similar manner ${ }^{105}$. But while Socrates clearly points to the Forum of Constantine as the place where his agony began only to finally end at the back of the square, Sozomenus does not specify the location of the latrine where Arius was to die. In an attempt to lend credibility to his account, he quoted a lengthy passage from Athanasius, bishop of Alexandria, in which the place of the heresiarch's death was given in detail ${ }^{106}$. One can assume that it was the issue of that location that led the historian to quote a rather lengthy citation from the work by Athanasius, who was held in great esteem at that time, although generally Sozomenus rarely referred the citations in his History ${ }^{107}$.

Sozomenus' complete silence on the subject of the Column must seem perplexing, all the more so if we agree with the thesis that this historian wrote his History with the work by Socrates in his hand. It is also mystifying since it was Sozomenus, unlike Socrates, who drew attention to the religious aspect of the foundation of Constantinople. It was him who wrote of Constantinople as the city of Christ, with no pagan cults ${ }^{108}$. It is in his account that Constantine acted on the instructions of God himself, who chose Byzantium as his new capital. The emperor, obeying his orders, expanded the area of the city, surrounded it with walls, developed it, populated with the people he had brought from the Old Rome and gave it the name New Rome - Constantinople. The ruler's efforts

\footnotetext{
${ }^{105}$ Sozomenus (II, 29) points to different interpretations of Arius' death.

${ }^{106}$ Sozomenus, II, 30, p. 364-368; the account by Socrates and Sozomenus on the death of Arius depends on the Athanasian sources: Epistula ad episcopos Aegypti et Libyae 18-19, and his Epistula ad Serapionem de morte Arii.

${ }^{107}$ S. Bralewski, Obraz papiestwa w historiografii kościelnej wczesnego Bizancjum, Łódź 2006, p. $272[=\mathrm{BL}, 10]$.

${ }^{108}$ Sozomenus, II, 3. This is inconsistent with the first ceremony of the foundation of the city of a decidedly pagan character held in the year 324 (more on the subject, see: G. DAGRON, op. cit., p. 29-47, 373) as well as other sources: Zosimus, Historia nova, II, 31, 2-3, ed. L. MendeLssohn, Lipsiae 1887; Hesychius, 41, p. 15-16. M. SALAmon (Rozwój idei Rzymu-Konstantynopola od IV do pierwszej połowy VI wieku, Katowice 1975, p. 78 [= PNUŚ, 80]) pointed out that the belief in the lack of pagan tradition in the Eastern capitol was the consequence of its having been founded by a Christian ruler, and the idea itself contributed over the subsequent centuries to an increase of tension between the two capitol dioceses.
} 
make his new capital an equal of the Italian Rome ${ }^{109}$ were successful also by the grace of God, because through it, the city grew to such an extent that the number of inhabitants and its wealth exceeded those of the former one. God gave support to the enthusiasm of the emperor and, through his revelations, confirmed the sanctity of churches the ruler built. Thus, in Sozomenus' version, the new capital was equated with the old; it became a participant of its precedence, equal to the first in terms of honour ${ }^{110}$.

As can be suspected, therefore, Sozomenus' silence on the subject of the Porphyry Column was not accidental, all the more so that we know from elsewhere that in other matters he was given to omitting facts inconvenient for his ideas ${ }^{111}$. Most probably, then, he did not mention the Porphyry Column because of its dual character, which made it possible for Christians and pagans to see it as their sacred monument. It seems that Eusebius of Caesarea never wrote about it in his biography of emperor Constantine for the same reason ${ }^{112}$. Perhaps Sozomenus rejected the account on the relics of the Holy Cross placed in the Column standing at the Forum of Constantine. This would also indicate that not everyone in the mid-fifth century saw it as an object of Christian worship and therefore some part of the inhabitants of Constantinople did not share the belief in the relics of the Cross of Christ hidden there.

Abstract. The complicated fates of the Porphyry Column of emperor Constantine resemble the reach and difficult history of Constantinople, the New Rome and capital of the eastern Empire from its very beginnings. Perceived by the Constantinopolitans as both Christian and pagan monument, adorned with legends repeated and enriched by generations, it was always a landmark of the city. The article summarizes, compares and analyzes the accounts of Byzantine historians, showing continuity of tradition and the lasting role of the unique object in the very heart of political centre of the imperial capital.

Translated by Katarzyna Gucio

\author{
Sławomir Bralewski \\ Katedra Historii Bizancjum \\ Uniwersytet Łódzki \\ ul. A. Kamińskiego 27a \\ 90-219 Łódź, Polska \\ s.bralewski@o2.pl
}

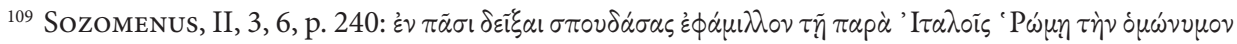

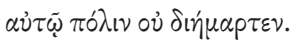

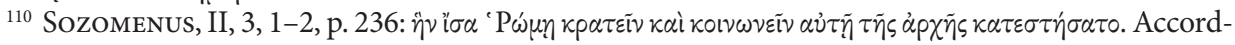
ing to F. Dvornik (Bizancjum a prymat Rzymu, trans. M. RAdożYCKA, Warszawa 1985, p. 30-31) moving the imperial seat to the East was a stimulus for the development of Peter's idea in Rome.

${ }^{111}$ As was the case with the papacy, cf. S. Bralewski, op. cit., passim.

${ }^{112}$ C. Mango, Constantine's Column..., p. 6.
} 